\title{
SCYPHOZOA PELAGIA NOCTILUCA (FORSSKAL, 1775): BLOOMING ON THE COAST OF GUJARAT, INDIA AND ITS PREDATION BY ANEMONIA VIRIDIS (FORSSKAL, 1775)
}

\author{
Geeta Padate*, Ruzbeh Mirza, Ankita Viradiya and Sunita Salunke
}

Department of Zoology, Faculty of Science, The Maharaja Sayajirao University of Baroda, Vadodara, India *Corresponding author. Email: gs.padate-zoo@msubaroda.ac

\author{
Article history \\ Received: 8 May 2020; \\ accepted 25 November 2020

\section{Keywords:} \\ Pelagia noctiluca; \\ Anemonia viridis; jellyfish \\ blooms; feeding behaviour; \\ Gujarat
}

\begin{abstract}
The jellyfish bloom, i.e. the aggregation of Pelagia noctiluca, which occurred in January 2016 along the Shivrajpur coast facing the Arabian Sea, is reported. The jellyfish population was studied based on the Pelagia noctiluca individuals that were stranded in low tide pools and those that were washed ashore. Transects were laid to collect data on the jellyfish density. The oceanographic and physicochemical parameters at the time of bloom were studied. The probability of correlation between the time of bloom and the movement of $P$. noctiluca was considered. Additionally, mating and predation on the species were documented. We assume that the jellyfish bloom might have drifted to this coast due to the landlocked characteristics of the Arabian Sea and northward movements of sea currents. So far, jellyfish has been known to be the dietary preference of several vertebrate predators. Here, we report an interesting event of Anemonia viridis feeding on Pelagia noctiluca during their blooms in several intertidal pools on the coast.
\end{abstract}

\section{INTRODUCTION}

Jellyfish, a class of marine cnidarians found in every ocean from the surface to the deep sea, form an important component of oceanic food webs (Canepa et al. 2014). These attractive, colorful, fluorescent and bell-shaped groups with stinging cells cnidocytes are of great importance due to their occasional blooming, which poses threat to swimmers and tourists, fishing, power plant operations (Purcell et al. 2007; Mariottini et al. 2008), aquaculture, energy, and ecosystem functioning (Canepa et al. 2014) etc. Mauve stinger (Pelagia noctiluca), a holoplanktonic scyphozoan, is known to populate various oceans including the warm subtropical waters of the Gulf of Mexico and the Mediterranean Sea (Miller et al. 2012), the temperate waters of the North Sea and also those of the North and South Atlantic (Purcell 2005; Doyle et al. 2008; Miller et al. 2012). Pelagia noctiluca, which lacks the polyp stage (Arai 2001), is an important nonselective planktonic predator (Larson 1987; Morand et al. 1987; Sandrini and Avian 1989; Giorgi et al. 1991; Rosa et al. 2013) feeding on almost all types of zooplankton and ichthyoplankton (Giorgi et al. 1991; Zavodnik 1991; Malej et al. 1993; Sabatés et al. 2010; Rosa et al. 2013). They are moderately predated by sea turtles, several species of fish (Doyle et al. 2014; Milisenda et al. 2014) as well as by Sea Anemone (Brueggeman 1998; Fautin and Fitt 1991). Due to its severe impacts on human activities, it attracts great scholarly interest (Canepa et al. 2014).

In the Western Mediterranean Sea, blooms of Pelagia noctiluca (Figure 1) have been observed as present/ absent for several years with a periodicity of 10-12 years since the beginning of the 1980s (Goy et al. 1989; Canepa et al. 2014). It was considered that optimal climatic conditions favour its growth and reproduction, while such established conditions as mild winter, low rainfall, high temperature and high atmospheric pressure its blooms (Canepa et al. 2014). They are potential indicators of ecosystem and/or climate changes (Hays et al. 2005; Hay 2006). As they move to deeper layers during the day (Franqueville 1971) with pulsating vertical movements, they are believed to play an important role in the mixing of ocean layers (Katija and Dabiri 2009; Leshansky and Pismen 2010). The role of such organelles in carbon capture and advection to the deep ocean has also been emphasized (Fenaux 1998; Costello et al. 2008; Doyle et al. 2014).

The explanation of frequent blooms of Pelagia noctiluca, an important component of marine food webs (Canepa et al. 2014), by the same reasons as those for the blooms of several other species, was not convincing (Mariottini et al. 2008). Hence, a project aimed at conducting scientific research on jellyfish in the Mediterranean Sea was launched under the UNEP through the Mediterranean Action Plan (MAP). As a result, there were two workshops held (in 1983 and in 1987) (Goy 1983; Giorgi et al. 1991), during which all the information available on $P$. noctiluca blooms in the Mediterranean was assembled (Canepa et al. 2014). P. noctiluca, which is known both for its positive and negative aspects, is important to human beings as its fluorescent proteins are 
used as genetic markers in detecting protein movement or gene expression in developmental, environmental and medical biology (Manning 1997).

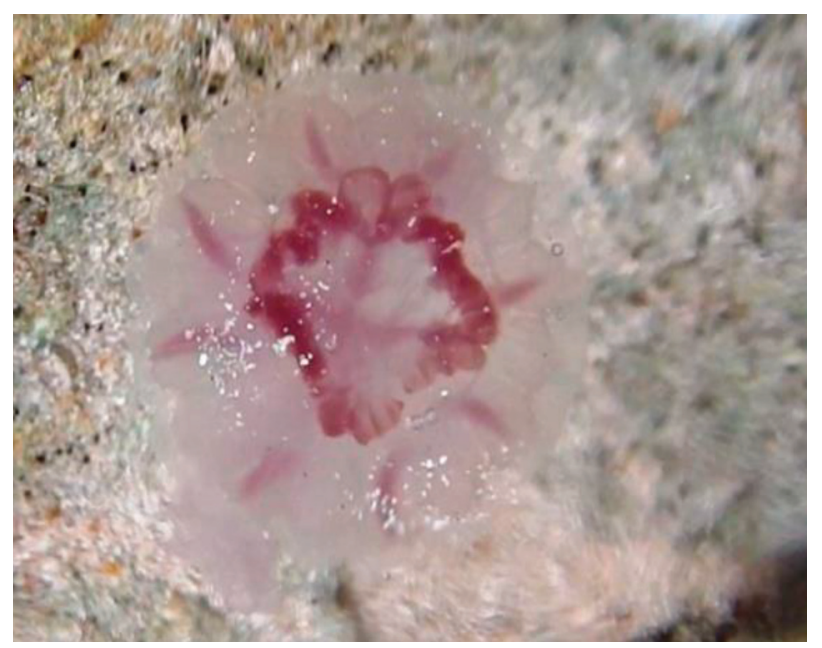

Figure 1. Pelagia noctiluca: aboral view.

Although P. noctiluca is a widespread species, records of its occurrence along the Indian coast are scanty. Nevertheless, blooms of jellyfish species have been reported from different parts of the Indian coast, e.g. the Arabian Sea off Mumbai (Chopra 1960), the Chennai coast (Masilamoni et al. 2000), Jakhau, the northern Gulf of Kachchh (Anonymous 2010), Goa (Fernandes 2012) and Dhalabali (the Chilika mouth), Gopalpur and, the Rushikulya mouth on the southern Odisha coast (Sahu and Panigrahy 2013, Baliarsingh et al. 2015). So far, $P$. noctiluca has been reported from the Arabian Sea and the Gulf of Oman (Stiasny 1937), the Iranian Gulf (Kramp 1956) and, recently, from the coast of Pakistan (Gul and Morandini 2013). In India, P. noctiluca has been reported from the southeast of Tamil Nadu as well as from the coast of Kerala (Ramakrishna and Sarkar 2003) and the Andaman Sea (Venkataraman et al. 2012). The only record of $P$. noctiluca from Gujarat is at Mithapur, about $20 \mathrm{~km}$ north of the Shivrajpur reef by Subburaman et al. (2014), however, with uncertainty regarding its identification. The present documentation of P. noctiluca is expected to contribute to the information available on environmental parameters and to deepen the understanding of the ecology of the species.

Jellyfish blooms are unpredictable. On the 5th of January, 2016, during our visit to the Shivrajpur Coast, a large number of Pelagia noctiluca individuals were found lying on the sandy coast and stranded in intertidal pools together with several other marine species. The pulsating jellyfish found in rock pools and those on the shore were immediately counted. Water samples were also collected for the analysis of salinity, $\mathrm{pH}, \mathrm{DO}$, and such nutrients as Nitrates, Nitrites, and Phosphates. We also recorded water temperature hoping that these characteristics may throw some light on the causes of the jellyfish bloom. To our surprise, we also observed the Sea Anemone Anemonia viridis feeding on P. noctiluca.

\section{MATERIALS AND METHODS}

Shivrajpur, falls into the district Devbhumi Dwarka, Gujarat. At the time of study, it was an undisturbed coral reef facing the Arabian Sea on the west coast of Saurashtra peninsula $\left(22^{\circ} 19^{\prime} 54^{\prime \prime} \mathrm{N} 68^{\circ} 57^{\prime} 12^{\prime \prime} \mathrm{E}\right)$. This reef has a rocky intertidal zone on the southern side and a sandy shore on the northern side (Figure 2). At present the Government of Gujarat is developing it as a blue flag beach.

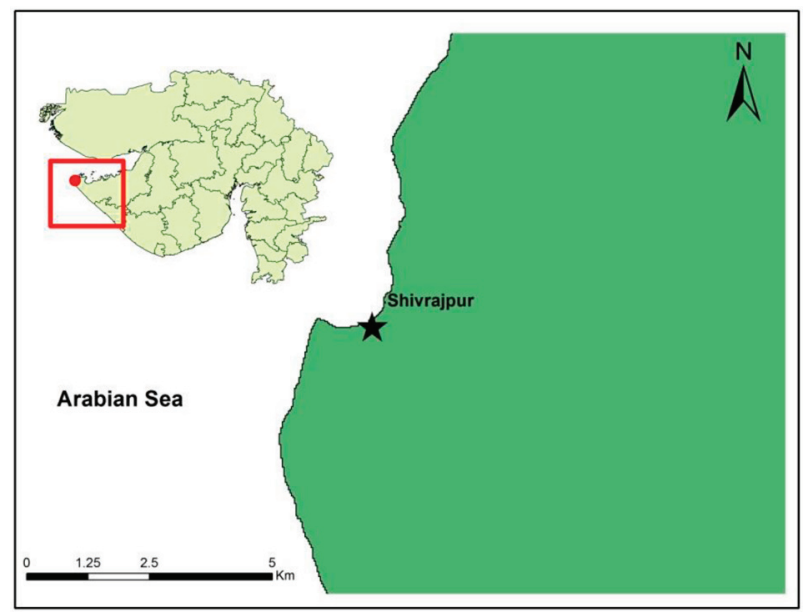

Figure 2. Location of Shivarajpur on the Saurashtra coast of Gujarat, India.

After large numbers of jellyfish, both swimming in tidal pools and lying on the coast, had been observed, field surveys were immediately planned on the 5th and 7 th of January 2016 between 9 am and $3 \mathrm{pm}$. The live jellyfish individuals trapped in intertidal rock pools were counted per pool irrespective of the pool size. In addition, intertidal pools with the presence of both jellyfish and Sea Anemone individuals were selected and the feeding behavior of Sea Anemone on jellyfish was recorded. The number of jellyfish individuals lying on the sandy beach was estimated in 200 quadrats of 1 square meter $(1 \mathrm{~m} \times 1 \mathrm{~m})$, spaced at every 10 meters along a $2 \mathrm{~km}$ long transect belt parallel to the sea. Photographs were taken using a Nikon coolpix AW120 digital camera. For water parameters, the coastal water temperature, DO, $\mathrm{NO}_{2}^{-}, \mathrm{NO}_{3}^{-}, \mathrm{PO}_{4}{ }^{3-}, \mathrm{pH}$ and Salinity were measured by the methods described in ICMAM protocol (Kaisary et al. 2012). To disclose any possible differences, water samples were collected on the day of bloom and two days after it. 


\section{RESULTS}

\section{P. noctiluca bloom:}

The density of P. noctiluca (Table 1, Figures 3 and 4).

Table 1. The mean count of jellyfish individuals on the beach and in rock pools on the $5^{\text {th }}$ of January in 2016 with Sea Anemone at the Shivrajpur coast.

\begin{tabular}{|l|c|c|c|c|}
\hline & Mean & SE & N & Total count \\
\hline $\begin{array}{l}\text { Live jellyfish/rock pool } \\
\text { (irrespective of size) }\end{array}$ & 26.45 & 2.8 & 20 & 529 \\
\hline Jellyfish lying on beach/m ${ }^{2}$ & 14.37 & 0.4 & 200 & 2875 \\
\hline Sea Anemone/rock pool & 6.15 & 1.07 & 20 & 123 \\
\hline
\end{tabular}

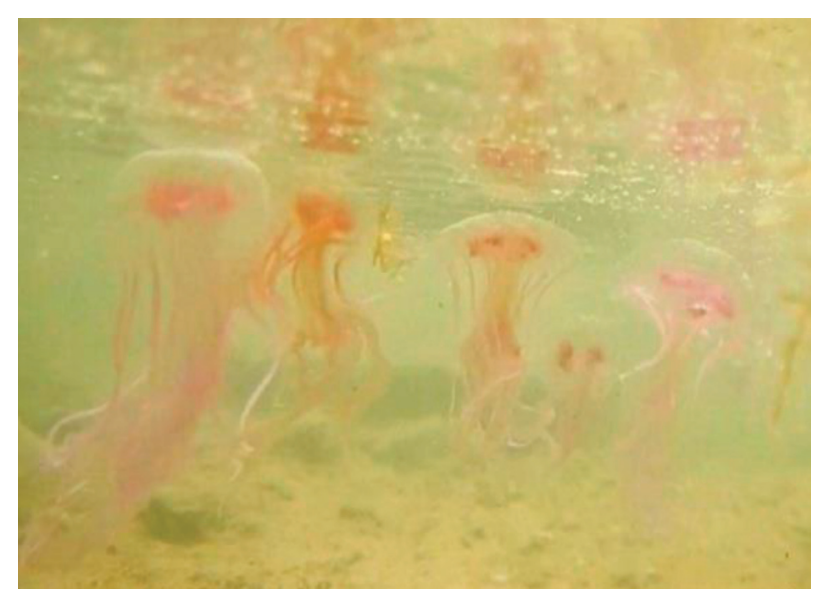

Figure 3. The bloom of pink and brownish morphs of Pelagia noctiluca.

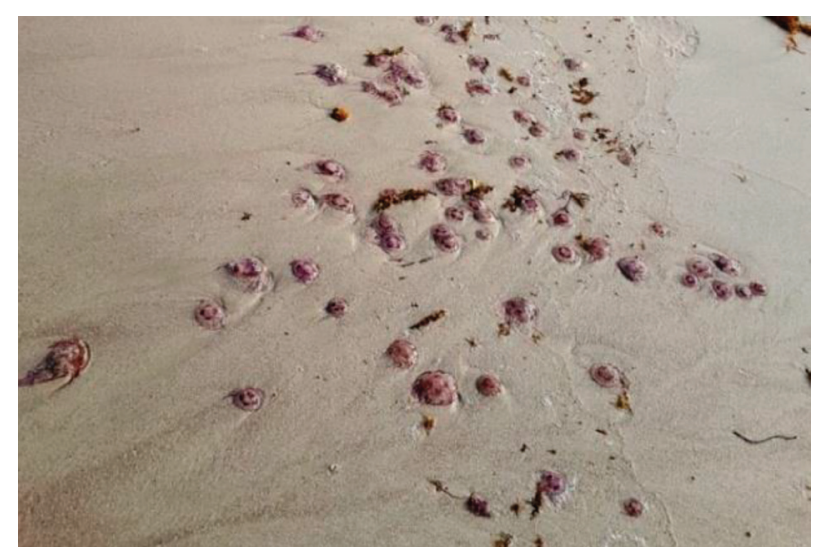

Figure 4. Pelagia noctiluca on the Shivrajpur beach.

Twenty different sized rock pools were surveyed in an 18-hectare intertidal zone at low tide. A total of 529 live $P$. noctiluca individuals were counted with a Mean of $26.45 \pm 2.82 \mathrm{SE}$ individuals/pool. Furthermore, a total of 2875 jellyfish individuals with a Mean of $14.37 \pm$ $0.49 \mathrm{SE}$ Individuals $/ \mathrm{m}^{2}$ were counted within a $2 \mathrm{~km}-$ long sandy beach transect with 200 quadrats. Both these numbers indicate the $P$. noctiluca bloom.
Results of the physicochemical analysis of the seawater from the same region for two days are given in Table 2. The water temperature ranged from $24^{\circ} \mathrm{C}$ to $25^{\circ} \mathrm{C}$. The $\mathrm{pH}$ and $\mathrm{DO}$ of the seawater remained the same at 7.9 and $8 \mathrm{mg} / 1$ respectively on both these days and Salinity was almost constant around $36 \mathrm{ppm}$. Within two days, $\mathrm{NO}_{3}{ }^{-}$showed a decrease from $1.9 \mu \mathrm{m} / 1$ to $1.1 \mu \mathrm{m} / 1$, while $\mathrm{NO}_{2}{ }^{-}$remained almost constant at $0.89 \mu \mathrm{m} / \mathrm{l}$ and $0.83 \mu \mathrm{m} / 1$, respectively, whereas $\mathrm{PO}_{4}{ }^{3-}$ exhibited an insignificant increase from $2.45 \mu \mathrm{m} / 1$ to $2.7 \mu \mathrm{m} / 1$.

Table 2. Physico-chemical characteristics of sea water on the $5^{\text {th }}$ and $7^{\text {th }}$ of January in 2016 at the Shivrajpur Coast during P. noctiluca bloom.

\begin{tabular}{|c|c|c|c|c|c|c|c|}
\hline Sample & $\begin{array}{c}\text { Temp } \\
\left({ }^{\circ} \mathrm{C}\right)\end{array}$ & $\mathrm{pH}$ & $\begin{array}{c}\mathrm{DO} \\
(\mathrm{mg} / \mathrm{l})\end{array}$ & $\begin{array}{c}\text { Salinity } \\
(\mathrm{ppm})\end{array}$ & $\begin{array}{c}\mathrm{NO}_{3}^{-} \\
\mu \mathrm{m} / 1\end{array}$ & $\begin{array}{c}\mathrm{NO}_{2}^{-} \\
\mu \mathrm{m} / 1\end{array}$ & $\begin{array}{c}\mathrm{PO}_{4}{ }^{3-} \\
\mu \mathrm{m} / 1\end{array}$ \\
\hline $\begin{array}{c}\text { 5 January } \\
\text { 2016 }\end{array}$ & 24.9 & 7.9 & 8.1 & 36.7 & 1.9 & 0.89 & 2.45 \\
\hline $\begin{array}{c}\text { 7 January } \\
\text { 2016 }\end{array}$ & 25.5 & 7.9 & 8.2 & 36.8 & 1.1 & 0.83 & 2.7 \\
\hline
\end{tabular}

\section{P. noctiluca - Anemonia viridis associations}

Sixteen out of the 20 rock pools surveyed showed the presence of Sea Anemone Anemonia viridis (Figures 5 and 6) occurring both solitarily and in colonies. A total of 123 A. viridis individuals were recorded in the area with a mean of $6.15 \pm 1.07$ individuals/pool.

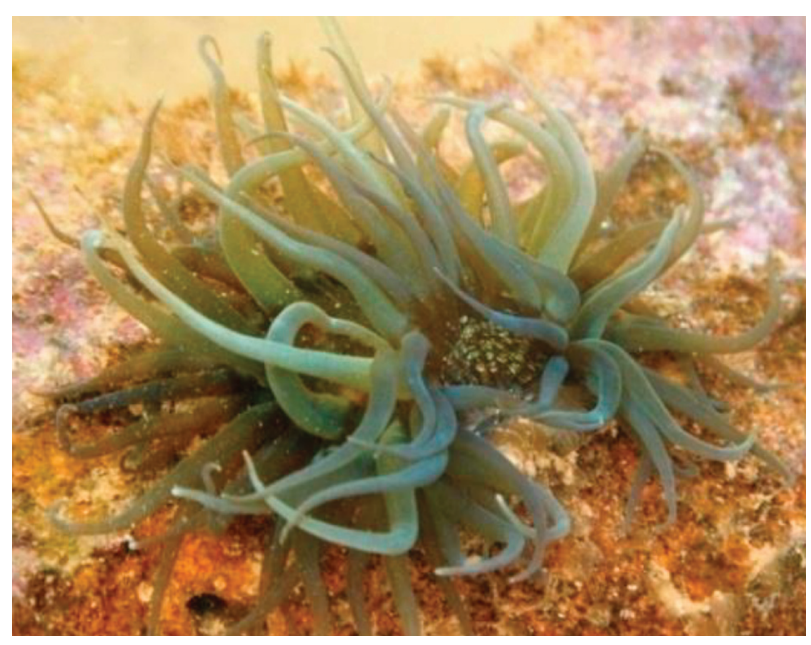

Figure 5. Anemonia viridis.

\section{Observation of the relationship between Anemonia viridis and $P$. noctiluca}

We observed $P$. noctiluca clinging onto tentacles of A. viridis in several intertidal pools (Figure 7). On closer examination, it turned out that Sea Anemone was predating on jellyfish. The feeding behavior of $A$. viridis on $P$. noctiluca was recorded on video (Supplementary information). 


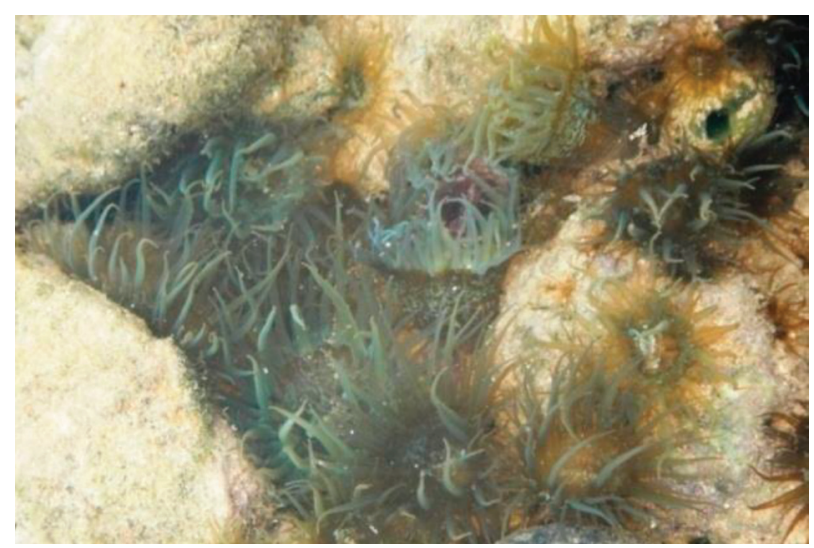

Figure 6. A colony of Anemonia viridis.

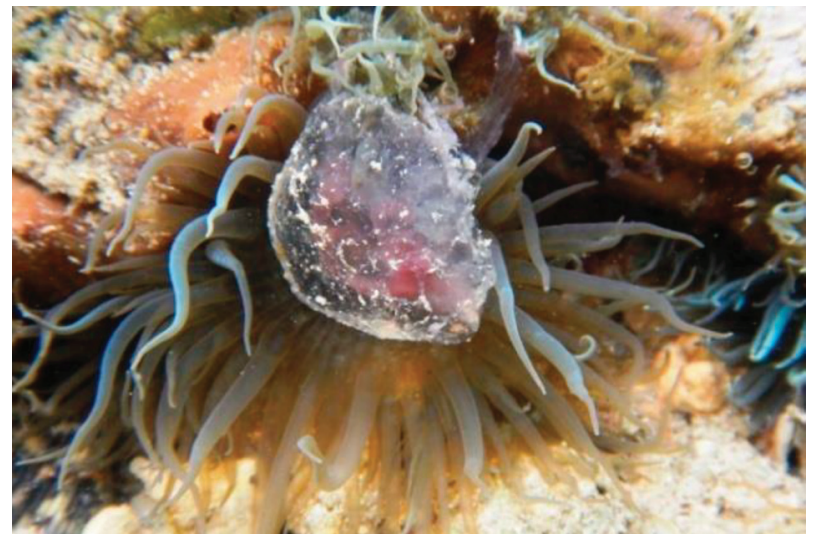

Figure 7. Anemonia viridis feeding on Pelagia noctiluca.

$P$. noctiluca shows up and down movements in intertidal rock pools along with tidal waves. We observed that when a jellyfish individual swims towards the bottom of tidal pools, it is captured by $A$. viridis with the help of its slender tentacles. The captured jellyfish individual starts pulsating its bell so as to escape from the tentacles of Sea Anemone. The observation also showed that as the jellyfish individual tries to swim away from the Sea Anemone, the latter drags it towards its mouth (Figure 7) and slowly devours the prey in about 90 to 120 minutes (Supplementary information).

\section{DISCUSSION}

Studies on stranded jellyfish are important in elucidating patterns of seasonality and population dynamics (Houghton et al. 2007). During the P. noctiluca bloom at the coast of Shivrajpur, $14.37 \mathrm{~m}^{-2}$ jellyfish individuals $\left(>1 / \mathrm{m}^{2}\right)$ were found stranded on the beach and 26.45 \pm 2.8 individuals were found trapped per rock pool, which definitely indicated the category " 3 " $\left(>1 / \mathrm{m}^{2}\right)$ jellyfish bloom as per Canepa et al. (2014). According to the Spanish National Research Council, when the density of $P$. noctiluca reaches this level, bathing and swimming activities at the seashore are prohibited. The laboratory life span of $P$. noctiluca has been reported to be about 1 year (Malej and Malej 1992) and only one report available indicates it to be more than a year in the wild (Lilley et al. 2014). When prey availability is sufficient, $P$. noctiluca show constant growth, whereas in the case of food shortage, they decrease in size, thereby minimizing the effect of poor nutrition or starvation (Larson 1987). Thus, the maturation of their gonads probably depends on the abundance of food (Lilley et al. 2014). Peculiarities of their lifecycle help jellyfish adapt to highly variable environments. In addition, they are also known to adapt to resources that are abundant temporarily (Boero et al. 2008; Richardson et al. 2009). They survive in extremely unfavorable conditions and can withstand periods of starvation (Larson 1987), and multiply rapidly when conditions become favorable. $P$. noctiluca are renowned for their outbreaks in the Mediterranean and Andes Seas. Thus, a series of phase shifts with a remarkable phylogenetic regression in the dominance of $P$. noctiluca is believed to be due to disruptions in the food web.

According to the long-term study (1976-1983) results reported by Tegaccia and Tegaccia (1983), the highest densities of $P$. noctiluca in the Adriatic Sea occur in pelagic waters with high salinity and low nutrients. Overall, salinity has been indicated to influence jellyfish behavior and distribution (Catalano et al. 1985). The northern part of the Arabian Sea is known for its higher salinity because of lower rainfall, a higher rate of evaporation and a low freshwater input from the surrounding land (Qasim 1982). During the present bloom, water salinity was found to be around $37-38 \mathrm{ppm}$, which exceeds the average.

Mariottini et al. (2008) asserted that dense aggregations of $P$. noctiluca in coastal shallow waters are caused by wind currents and tides. Arabian Sea currents are known to be under the influence of Monsoon winds (Shetye et al. 1994). At the west coast of Saurashtra, the overall wind direction during January is from Northeast to Southwest, which induces the flow of Arabian Sea surface currents in the same direction. However, the subsurface Arabian Sea currents are from Southwest to Northeast (Shetye et al. 1994). Furthermore, these authors have also reported that an equatorial undercurrent supplies cool water that is entrained into the upper layer. The conditions favouring the formation of medusa blooms are temperatures $>10^{\circ} \mathrm{C}$ in winter and $<27^{\circ} \mathrm{C}$ in summer and salinities of 35-38 ppm (Purcell et al. 1999). Probably, these conditions occurred before January 2016 resulting in the $P$. noctiluca bloom in the region. The association between jellyfish stranding and wind speed needs to be interpreted with care because jellyfish can also be "washed ashore" by strong windgenerated waves (Canepa et al. 2014). P. noctiluca, which is a deep-sea species showing vertical movements 
(Katija and Dabiri 2009; Leshansky and Pismen 2010), could be assumed to have drifted towards the coast with these currents. The three important points that need to be taken into consideration are: (a) the Arabian Sea is landlocked on the northern side; (b) the inward current to the Gulf of Kachchh is probably pulling the bloom from the southern side towards the western coast of Gujarat at Shivrajpur coast; (c) the Gulf of Kachchh experiences the highest tidal fluctuations in the world because of its unique shape (Hashimi et al. 1978; Babu et al. 2005; Vethamony et al. 2005).

The sea surface temperature (SST) of the Arabian Sea usually fluctuates from $25^{\circ} \mathrm{C}$ to $28^{\circ} \mathrm{C}$ (Qasim 1982). However, the comparison of SST records for the last ten years (1996-2016) shows an increase in SST, which is explained by the impact of global warming (SST images NOAA-17 AVHRR-INTUOS ground station accessed from software SeaDAS). In 2016 the average SST of the Arabian Sea was $30^{\circ} \mathrm{C}$ (accessed on SeaDas, January 2018). Though this increase in SST was not very big, the distribution of temperature was wider, i.e. a wider area of the Arabian Sea showed a higher temperature. The influence of water temperature on the swimming behavior of $P$. noctiluca has been emphasized (RottiniSandrini 1982). Moreover, the occurrence of $P$. noctiluca aggregations in coastal waters of the Adriatic Sea in summer was also explained by this factor. The Arabian Sea is warming up faster than all other seas in the world (Ravichandran 2017; Times of India report), as the northernmost extent of its pole-ward boundary is closed (Shetye et al. 1994) and the release of heat towards north pole is prevented. In addition, there is an oxygen minimum zone in the Arabian Sea (Schulte et al. 1999), which is the outcome of very high productivity in the area (Smith et al. 1991). The spread of temperature to deeper areas of the Arabian Sea and its impact on the productivity of $P$. noctiluca cannot be ruled out.

The occurrence of $P$. noctiluca mainly during summer months has been associated with variations in environmental factors (Piccinetti and Piccinetti 1984, Piccinetti et al. 1991; Rottini-Sandrini and Stravisi 1981; See Richardson et al. 2009). Nevertheless, dry, warm and anti-cyclonic conditions in late spring favor the bloom of $P$. noctiluca during the forthcoming summer (Goy et al. 1989). P. noctiluca blooms have also been reported to occur from March to January in the Spotorno Bay (Western Ligurian Riviera), irrespective of the season (Carli et al. 1985). The conditions that are conducive to the bloom of medusa $P$. noctiluca are temperature $>10^{\circ} \mathrm{C}$ in winter and $<27^{\circ} \mathrm{C}$ in summer and salinities 35-38 ppm (Purcell et al. 1999). Early stages (ephyra larvae) of jellyfish are highly sensitive to food and water temperature conditions during late spring (Morand et al. 1992).

It has been hypothesized that oceanic warming as well as the removal of a top predator by overfishing has befitted jellyfish resulting in their frequent blooms (Purcell 2005; Lynam et al. 2006; Attrill et al. 2007). Such blooms have not been reported from the coast of Gujarat. Furthermore, the warming of the Arabian Sea, overfishing and removal of top predators in this highly productive area are likely to be the causes of frequent jellyfish blooms. The coral reef at Shivrajpur, which supports a great diversity of other reef fauna, is also ecologically very important. If jellyfish blooms occur frequently, in the future the beach may be no longer safe for tourists because of the threat of venomous stings by jellyfish.

\section{Anemonia viridis feeding on Pelagia noctiluca}

Though jellyfish are known to play an important role both as prey and predators of several animals (Purcell 1997; Arai 2005; Barz and Hirche 2007) in marine food webs, these coelenterates are usually considered to be poor prey because they are digested very rapidly (Arai 2005 ) and because of their stinging nature. Sommer et al. (2002) considered jellyfish as dead ends in the pelagic food web because of their low nutritional value and high water and salt content relative to organic content. Although this makes them less important as items of food for vertebrates, there are some minor exceptions where some fish, turtles and birds feed on them. However, gelatinous species are fast digestible (and, presumably, fast assimilated) and, when in bloom, provide significant biomass. In addition to vertebrates, which are known to feed on gelatinous species, there are several opportunistic feeders which might feed on jellyfish when in bloom (Arai et al. 2003). This might be true for $P$. noctiluca at Shivrajpur coast. In this study, at least 6 out of the 123 Sea Anemone individuals in total $(6.15 \pm 1.07$ individuals/pool irrespective of size, Table 1) were observed feeding on $P$. noctiluca (Figure 6).

A. viridis, also called carpet anemone because of its carpet like assemblages, which provide habitat to various other organisms, is a component of the biocoenosis of photophilic soft algae (Pérès 1982). Though not recorded earlier from the Indian coast, it is the most well-known Sea Anemone (Chintiroglou and Koukouras 1992). It feeds on various invertebrates including minute crustaceans that are captured by its tentacles (Möller 1978). The feeding process of Anemonia sulcata (now Anemonia viridis) was described in detail by Pantin and Pantin (1943). Turbid and turbulent water conditions facilitate this type of capture (Sebens 1981). However, at Shivrajpur, $P$. noctiluca individuals were caught by Sea Anemone in clear water, which could be explained by the excessive abundance of the former and by the fact that they drifted to the coast and got trapped in low-tide pools, where they fell prey to $A$. viridis.

Data on $P$. noctiluca predation by a wide range of 
other carnivores such as molluscs, arthropods, reptiles and birds are accumulated more slowly (Arai 2005). A. viridis is consumed by people in many countries, e.g. Greece, Italy and Yugoslavia (Pax and Muller 1962). Hence, although the understanding of its biology, ecology and interactions with associated species is properly defined, its relative importance in ecology of benthic biocoenosis is still unclear. This study aims to provide data on P. noctiuca occurring along the Gujarat coast, India. It also contributes to a better understanding of their distribution and biocoenosis.

\section{FUNDING}

The present study was supported by the funding received from the Ministry of Earth Sciences, Government of India, as part of ESTC M K Bhavnagar University under the network project "Marine coastal ecology of west coast of India" Ref. No. MoES/16/06/2013-RDEAS.

\section{ACKNOWLEDGEMENTS}

The authors are thankful to the Ministry of Earth Sciences, Government of India, for funding the Project. Thanks are also due to PCCF Wildlife Gandhinagar Gujarat, India for granting permission to work in the coastal region of the Gulf of Kachchh vide Ref. No. WLP/28/C/126-27/2015-16 and Gujarat Biodiversity Board for granting permission to study the biodiversity of the area vide Ref. No. GBB/form-1/T-3b/1630/210516. Authors are thankful to CCF Jamnagar, for his permission, inputs and helpful discussions from time to time. Authors are also thankful to Mr. Sukanta Saha from the Department of Geography, The Maharaja Sayajirao University of Baroda, for producing a map of the study area for us.

\section{REFERENCES}

Anonymous. 2010. Research Highlight Seasonal jellyfish fishery in Jakhau, Gujarat. 'Cadalmin' CMFRI newsletter 127: 10.

Arai, M. N. 2001. Pelagic coelenterates and eutrophication: a review. Hydrobiologia 451: 69-87.

Arai, M. N. 2005. Predation on pelagic coelenterates: a review.Journal of the Marine Biological Association of the United Kingdom 85: 523-536.

Arai, M. N., D. W. Welch, A. L. Dunsmuir, M. C. Jacobs, and A. R. Ladouceur. 2003. Digestion of pelagic Ctenophora and Cnidaria by fish. Canadian Journal of Fisheries and Aquatic Sciences 60: 825-829.
Attrill, M. J., J. Wright, and M. Edwards. 2007. Climaterelated increases in jellyfish frequency suggest a more gelatinous future for the North Sea. Limnology and Oceanography 1: 480-485.

Babu, M. T., P. Vethamony, and E. Desa. 2005. Modelling tide-driven currents and residual eddies in the Gulf of Kachchh and their seasonal variability: A marine environmental planning perspective. Ecological Modelling184: 299-312.

Baliarsingh, S. K., S. Srichandan, K. C. Sahu, and A. A. Lotliker. 2015. Occurrence of a new species of toxic Cnidaria (Pelagia noctiluca Forskål, 1775) from estuarine waters of Rushikulya River, Western Bay of Bengal. Indian Journal of Geo-Marine Sciences 44: 580-582.

Barz, K., and H. J. Hirche. 2007. Abundance, distribution and prey composition of scyphomedusae in the southern North Sea. Marine Biology 151: 1021-1033.

Boero, F., J. Bouillon, C. Gravili, M. P. Miglietta, T. Parsons, and S. Piraino. 2008. Gelatinous plankton: irregularities rule the world (sometimes). Marine Ecology Progress Series 356: 299-310.

Brueggeman, P. 1998. Cnidaria-Anthozoa: anemones, soft coral underwater field guide to ross island \& mcmurdo sound, Antarctica, 1-84 pp.

Canepa, A., V. Fuentes, A. Sabatés, S. Piraino, F. Boero, and J. M. Gili. 2014. Pelagia noctiluca in the Mediterranean Sea. In Jellyfish blooms 237-266. Springer, Dordrecht.

Carli, A., A. Aste, V. Balestra, and L. Pane. 1985. Presenza di meduse nella Baia di Spotorno (Mar Ligure). Nova Thalassia 7: 151-155.

Catalano, G., M. Avian, and R. Zanelli. 1985. Influence of salinity on the behaviour of Pelagia noctiluca (Forskål) (Scyphozoa, Semaeostomeae). Oebalia 9: 169-179.

Chintiroglou, C., and A. Koukouras. 1992. A population of the sea anemone Anemonia viridis (Förskal, 1775) and its associated flora and fauna, in the North Aegean Sea. Internationale Revue der gesamten Hydrobiologie und Hydrographie 77: 483-495.

Chopra, S. 1960. A note on the sudden outburst of ctenophores and medusae in the waters off Bombay. Current Science 29: 392-393.

Costello, J. H., S. P. Colin, and J. O. Dabiri. 2008. Medusan morphospace: phylogenetic constraints, biomechanical solutions, and ecological consequences. Invertebrate Biology 127: 265-290.

Doyle, T. K., H. De Haas, D. Cotton, B. Dorschel, V. Cummins, J. D. Houghton, J. Davenport, and G. C. Hays. 2008. Widespread occurrence of the jellyfish Pelagia noctiluca in Irish coastal and shelf waters. Journal of Plankton Research 30: 963-968.

Doyle, T. K., G. C. Hays, C. Harrod, and J. D. Houghton. 2014. Ecological and societal benefits of jellyfish. In Jellyfish blooms, 105-127. Springer, Dordrecht.

Fautin, D. G., and W. K. Fitt. 1991. June. A jellyfish-eating 
sea anemone (Cnidaria, Actiniaria) from Palau: Entacmaea medusivora sp. nov. In Hydrobiologia 216: 453-461. Kluwer Academic Publishers.

Fenaux, R. 1998. Life history of the Appendicularia. The Biology of Pelagic Tunicates: 151-159.

Fernandes, P. 2012. http://articles. timesofindia.indiatimes. com/2012-10-22/ goa/34652815_1_moon-jellyfishportuguese-man-o-war-bigger-fish.

Franqueville, C. 1971. Macroplancton profound (invertébrés) de la Méditerranée Nord-occidentale. Tethys 3:11-56.

Garg, A., and V. Singh. 2013. Jellyfish bloom along the south Odisha coast, Bay of Bengal. Current Science 104: 410.

Giorgi, R., M. Avian, S. De. Olazabal, and L. Rottini Sandrini. 1991. Feeding of Pelagia noctiluca in open sea. In Proceedings of the II Workshop on Jelly-Fish in the Mediterranean Sea 47: 102-111. UNEP.

Goy, J. 1983. October. Les concentrations de méduses en Mer Ligure. In Workshop on Jellyfish Blooms in the Mediterranean, 109-120. Athens, Greece, 31 October -4 November.

Goy, J., P. Morand, and M. Etienne. 1989. Long-term fluctuations of Pelagia noctiluca (Cnidaria, Scyphomedusa) in the western Mediterranean Sea. Prediction by climatic variables. Deep Sea Research Part A. Oceanographic Research Papers 36: 269-279.

Gul, S., and A. C. Morandini. 2013. New records of scyphomedusae from Pakistan coast: Catostylus perezi and Pelagia cf. noctiluca (Cnidaria: Scyphozoa). Marine Biodiversity Records 6.

Hashimi, N. H., R. R. Nair, and R. M. Kidwai. 1978. Sediments of the Gulf of Kutch-A high energy tide dominated environment. Indian Journal of Marine Sciences 7: 1-7.

Hay, S. 2006. Marine ecology: gelatinous bells may ring change in marine ecosystems. Current Biology 16: 679-682.

Hays, G. C., A. J. Richardson, and C. Robinson. 2005. Climate change and marine plankton. Trends in Ecology and Evolution 20: 337-344.

Houghton, J. D. R., T. K. Doyle, J. Davenport, M. K. Lilley, R. P. Wilson, and G. C. Hays. 2007. Stranding events provide indirect insights into the seasonality and persistence of jellyfish medusae (Cnidaria: Scyphozoa). Hydrobiologia 589: 1-13.

Kaisary, S., K. Narendra Babu, Dileep Kumar Balasubramanian, M. Patra, S. Sundaramoorthy, and B. R. Subramanian. 2012. Coastal Water Quality Measurements Protocol for COMAPS Programme. ICMAM Project Directorate, Chennai.

Katija, K., and J. O. Dabiri. 2009. A viscosity-enhanced mechanism for biogenic ocean mixing. Nature 460: 624.

Kramp, P. L. 1956. Medusae of the Iranian gulf. Videnskabelige Meddelelser fra Dansk Naturhistorik Forening 118: 235-242.
Larson, R. J. 1987. A note on the feeding, growth, and reproduction of the epipelagic scyphomedusa Pelagia noctiluca (Forskål). Biological Oceanography 4: 447-454.

Leshansky, A. M., and L. M. Pismen. 2010. Do small swimmers mix the ocean? Physical Review E 82: 025301.

Lilley, M. K., M. Ferraris, A. Elineau, L. Berline, P. Cuvilliers, L. Gilletta, A. Thiéry, G. Gorsky, and F. Lombard. 2014. Culture and growth of the jellyfish Pelagia noctiluca in the laboratory. Marine Ecology Progress Series 510: 265-273.

Lynam, C. P., M. J.Gibbons, B. E. Axelsen, C. A. Sparks, J. Coetzee, B G Heywood, and A. S. Brierley. 2006. Jellyfish overtake fish in a heavily fished ecosystem. Current biology 13: 492-493.

Malej, A., and M. Malej. 1992. Population Dynamics of the jellyfish Pelagia noctiluca (Forsskal 1775). In Marine Eutrophication and population Dynamics, edited by G. Colombo et al., 215-219. Denmark: Olsen and Olsen Frendensborg.

Malej, A., J. Faganeli, and J. Pezdič. 1993. Stable isotope and biochemical fractionation in the marine pelagic food chain: the jellyfish Pelagia noctiluca and net zooplankton. Marine Biology 116: 565-570.

Manning, E. 1997. Glow fish Bioscience. Zoology 47: $135-138$.

Mariottini, G., E. Giacco, and L. Pane. 2008. The Mauve Stinger Pelagia noctiluca (Forsskål, 1775) Distribution, Ecology, Toxicity and Epidemiology of Stings. Marine Drugs 6: 496-513.

Masilamoni, J. G., K. S. Jesudoss, K. Nandakumar, K. K. Satpathy, K. V. K. Nair, and J. Azariah. 2000. Jellyfish ingress: a threat to the smooth operation of coastal power plants. Current Science 79: 567-569.

Milisenda, G., S. Rosa, V. L. Fuentes, F. Boero, L. Guglielmo, J. E. Purcell, and S. Piraino. 2014. Jellyfish as prey: frequency of predation and selective foraging of Boops boops (Vertebrata, Actinopterygii) on the mauve stinger Pelagia noctiluca (Cnidaria, Scyphozoa). PLoS one 9: 94600.

Miller, B. J., S. Von der Heyden, and M. J. Gibbons. 2012. Significant population genetic structuring of the holoplanktic scyphozoan Pelagia noctiluca in the Atlantic Ocean. African Journal of Marine Science 34: 425-430.

Möller, H. 1978. Nahrungsökologische Untersuchungen an Anemonia sulcata. Zoologischer Anzeiger 200: 369-373.

Morand, P., C. Carré, and D. C. Biggs. 1987. Feeding and metabolism of the jellyfish Pelagia noctiluca (scyphomedusae, semaeostomae). Journal of Plankton Research 9: 651-665.

Morand, P., J. Goy, and S. Dallot. 1992. Recrutement et fluctuations à long-terme de Pelagia noctiluca (Cnidaria, Scyphozoa). Annals of the Institute of Oceanography 68: 151-158. 
Pantin, C. F. A., and A. M. P. Pantin. 1943. The stimulus to feeding in Anemonia sulcata. Journal of Experimental Biology 1: 6-13.

Pax, F., and J. Müller. 1962. Die Anthozoen fauna der Adria. Fauna et Flora Adriatica, Split 3: 1-343.

Pérès, J. M. 1982. Zonations organismic assemblages. In Marine Ecology, Vol. V, Ocean management, edited by Kinne, O. Part 1: 9-576. Wiley, Chichester.

Piccinetti, C., and G. Piccinetti Mandrin. 1984. Distribuzione di Pelagia noctiluca in Adriatico dal 1976 al 1983. Nova Thalassia 6: 1-68.

Piccinetti, C., G. Piccinetti Manfrin, and M. Fiorentini. 1991. Observations ulterieures sur la dynamique de Pelagia noctiluca. In Jellyfish blooms in the Mediterranean, Proceedings of the II Workshop on Jellyfish in the Mediterranean Sea.MAP Technical Reports Series 47: 141-146.

Purcell, J. E. 1997. Pelagic cnidarians and ctenophores as predators: selective predation, feeding rates, and effects on prey populations. Annales de l'Institut océanographique: 2.

Purcell, J. E. 2005. Climate effects on formation of jellyfish and ctenophore blooms: a review. Journal of the Marine Biological Association of the United kingdom 85: 461-476.

Purcell, J. E., A. Malej, and A. Benović. 1999. Potential Links of Jellyfish to Eutrophication. Coastal and estuarine studies 55: 241-263.

Purcell, J. E., S. I. Uye, and W. T. Lo. 2007. Anthropogenic causes of jellyfish blooms and their direct consequences for humans: a review. Marine Ecology Progress Series 350: 153-174.

Qasim, S. Z. 1982. Oceanography of the northern Arabian Sea. Deep Sea Research Part A. Oceanographic Research Papers 299: 1041-1068.

Ramakrishna, A., and J. Sarkar. 2003. On the Scyphozoa From East Coast of India, Including Andaman \& Nicobar Islands. Rec. Zool. Surv. India 101: 25-56.

Ravichandran, M. 2017. https://timesofindia.indiatimes. com/city/goa/indian-ocean-is-warming-faster-thanothers-says-ncaor/articleshow/58584020.cms (accessed on July 2017).

Richardson, A. J., A. Bakun, G. C. Hays, and M. J. Gibbons. 2009. The jellyfish joyride: causes, consequences and management responses to a more gelatinous future. Trends in Ecology and Evolution 24: 312-322.

Rosa, S., M. Pansera, A. Granata, and L. Guglielmo. 2013. Interannual variability, growth, reproduction and feeding of Pelagia noctiluca (Cnidaria: Scyphozoa) in the Straits of Messina (Central Mediterranean Sea): Linkages with temperature and diet. Journal of Marine Systems 111: 97-107.

Rottini-Sandrini, L. 1982. Effect of water temperature on the motility of Pelagia noctiluca (Forksal). Experientia 38: $453-454$
Rottini-Sandrini, L., and F. Stravisi. 1981. Preliminary report on the occurrence of Pelagia noctiluca. Rapp. Comm. Int. Mer Médit 27.

Sabatés, A., F. Pages, D. Atienza, V. Fuentes, J. E. Purcell, and J. M. Gili. 2010. Planktonic cnidarian distribution and feeding of Pelagia noctiluca in the NW Mediterranean Sea. In Jellyfish Blooms: New Problems and Solutions, 153-165.Springer, Dordrecht.

Sahu, B. K., and R. C. Panigrahy. 2013. Jellyfish bloom along the south Odisha coast, Bay of Bengal. Current Science 104: 410.

Sandrini, L. R., and M. Avian. 1989. Feeding mechanism of Pelagia noctiluca (Scyphozoa: Semaeostomeae); laboratory and open sea observations. Marine Biology 1021: 49-55.

Sebens, K. P. 1981. The allometry of feeding, energetics, and body size in three sea anemone species. The Biological Bulletin 161: 152-171.

Shetye, S. R., A. D. Gouveia, and S. S. C. Shenoi. 1994. Circulation and water masses of the Arabian Sea. Proceedings of the Indian Academy of Sciences-Earth and Planetary Sciences 103: 107-123.

Schulte, S., F. Rostek, E. Bard, J. Rullkötter, and O. Marchal. 1999. Variations of oxygen-minimum and primary productivity recorded in sediments of the Arabian Sea. Earth and Planetary Science Letters 173: 205-221.

Sommer, U., H. Stibor, A. Katechakis, F. Sommer, and T. Hansen. 2002. Pelagic food web configurations at different levels of nutrient richness and their implications for the ratio fish production: primary production. In Sustainable increase of marine harvesting: fundamental mechanisms and new concepts, 11-20. Springer, Dordrecht.

Stiasny, G. 1937. Scyphomedusae. Scientific Reports of the John Murray Expedition 1933-34 (4): 203-242.

Subburaman, S., S. Goutham, D. Joshi, M. Vanktesh, B. M. Proavinkumar, M. Matwal, R. D. Khambhoj, M. V. M. Wafar, R. Kaul, and B. C. Choudhury. 2014. Daring to Restore: Coral Reef recovery in Mithapur. Wildlife Trust of India.

Tegaccia, N., and T. Tegaccia. 1983. Condizioni idrologiche collegate alla presenza di Pelagia noctiluca in Adriatico. Nova Thalassia846: 59-64.

Venkataraman, K., C. Raghunathan, C. S. Sreeraj, and R. Raghuraman. 2012. Guide to the dangerous and venomous marine animals of India, 1-98. Kolkata: Published by the Director Zool Surv India.

Vethamony, P., G. S. Reddy, M. T Babu, E. Desa, and K. Sudheesh. 2005. Tidal eddies in a semi-enclosed basin: a model study. Marine Environmental Research 595: 519-532.

Zavodnik, D. 1991. On the food and feeding in the North Adriatic of Pelagia noctiluca (Scyphozoa). In Jellyfish blooms in the Mediterranean, Proceedings of II workshop on jellyfish in the Mediterranean Sea, Athens, UNEP. 